\title{
Preventing disability through understanding international megatrends in Deaf bilingual education
}

I M Munoz-Baell, C Alvarez-Dardet, M T Ruiz, R Ortiz, M L Esteban and E Ferreiro

$J$ Epidemiol Community Health 2008;62;131-137

doi:10.1136/jech.2006.059378

Updated information and services can be found at:

http://jech.bmj.com/cgi/content/full/62/2/131

\begin{abstract}
These include:
References This article cites 11 articles, 3 of which can be accessed free at: http://jech.bmj.com/cgi/content/full/62/2/131\#BIBL

1 online articles that cite this article can be accessed at: http://jech.bmj.com/cgi/content/full/62/2/131\#otherarticles

\section{Rapid responses You can respond to this article at: \\ http://jech.bmj.com/cgi/eletter-submit/62/2/131}

Email alerting Receive free email alerts when new articles cite this article - sign up in the box at service the top right corner of the article
\end{abstract}

Notes

To order reprints of this article go to:

http://journals.bmj.com/cgi/reprintform

To subscribe to Journal of Epidemiology and Community Health go to:

http://journals.bmj.com/subscriptions/ 


\title{
Preventing disability through understanding international megatrends in Deaf bilingual education
}

\author{
I M Munoz-Baell, ${ }^{1}$ C Alvarez-Dardet, ${ }^{2}$ M T Ruiz, ${ }^{2}$ R Ortiz, ${ }^{2}$ M L Esteban, ${ }^{3}$ E Ferreiro ${ }^{4}$
}

${ }^{1}$ Facultad de Educacion, Universidad de Alicante, Alicante, Spain; ${ }^{2}$ Departamento de Salud Publica, Universidad de Alicante, Alicante, Spain; ${ }^{3}$ Columbus (Center for Døve), Herlev, Denmark; ${ }^{4}$ Centro de Recursos para la Comunidad Sorda "Juan Luis Marroquín", Fundación CNSE para la Supresión de las Barreras de Comunicación, Madrid, Spain

Correspondence to: I M Munoz-Baell, Facultad de Educacion, Universidad de Alicante, 03080 Alicante, Spain; irmamu@ua.es

Accepted 1 April 2007

\begin{abstract}
Background: Education is a basic prerequisite for $\mathrm{d} /$ Deaf people's health. Deaf education varies considerably from country to country and we still know very little about the reasons for such variation.
\end{abstract}

Objective: To identify international megatrends that influence the current Deaf bilingual education move (Deaf Bilingual-Bicultural education; DBiBi) worldwide.

Methods: Using the Delphi technique, 41 experts in d/ Deaf education (nine Deaf, 32 hearing) from 18 countries identified, ranked, and rated international megatrends in DBiBi education.

Results: The process revealed six main essential elements of the international implementation of DBiBi education and nine main barriers against it. The top five promoting forces in that list in order of priority were: (1) societal and political changes towards a growing acceptance of diversity and Deaf issues; (2) growing Deaf activism, self-awareness and empowerment; (3) scientific research in sign linguistics and bilingualism; (4) changes in the d/Deaf educational community; and (5) international cooperation. The top five hindering forces included: (1) the view of deafness as a medical condition with a technological solution; (2) phonocentrism and societal resistance to the unknown; (3) educational and d/Deaf educational policies; (4) DBiBi education weaknesses; and (5) invisibility, heterogeneity and underperformance of the $d$ /Deaf population.

Conclusion: The results of this study reveal that social/ political changes and a medical/social model of Deaf people's health can promote or limit Deaf people's educational options much more than changes within the education system itself, and that a transnational perspective is needed in deciding how best to support DBiBi education at a national and local level in an increasingly globalised world.

Deafness is still a major cause of disability worldwide, and places an enormous social and economic burden on individuals and countries. ${ }^{12}$ Furthermore, because deafness is known to be an "invisible disability", d/Deaf people* are at an even greater risk of experiencing health problems throughout their lives than other disabled groups and therefore require special attention. Too often, disempowering childrearing and educational policies, and exclusionary healthcare provision and health-promoting programmes result in much higher levels of mental illness, sexual abuse and AIDS prevalence in $d /$ Deaf people than in the community as a whole. ${ }^{1247}$

Reducing inequities in health between and within countries has been a prime goal of health policy for decades. ${ }^{8}$ The European HEALTH21

\footnotetext{
* The word "Deaf", with an upper-case "D", refers to the culture and community of a particular group of deaf people who share a language - a sign language, whereas the word "deaf", with a lowercase " $d$ ", refers to the audiological inability to hear. ${ }^{3}$
}

policy reaffirmed the Ottawa Charter's commitment to address the broad determinants of health as a major strategy for achieving this goal. Education is a main determinant of health and a very strong predictor when making healthy choices. Too often disabled people, and in particular d/Deaf people, are not given easy access to appropriate education. As the first barriers to $d /$ Deaf people arise in childhood, the education of $\mathrm{d} /$ Deaf children constitutes a priority and the best strategy for laying the foundations for equal opportunities and combating marginalisation. ${ }^{19} 10$ Far from contributing towards ensuring a healthy start in life for Deaf people (Health For All target 3), past Deaf education seen only from a perspective of speech rehabilitation has not only increased communication barriers and disempowerment but has also jeopardised Deaf people's rights to use their first and preferred language. ${ }^{4} 1112$ Accordingly, as an alternative to traditional Deaf education, a bilingual model consisting of both an oral and a sign language (Deaf Bilingual-Bicultural education; $\mathrm{DBiBi}$ ) has been inexorably expanding and imposing itself with the support of the United Nations, UNESCO, the World Federation of the Deaf and the European Union ${ }^{4}{ }^{13-22}$ as an example of good practice in the education of Deaf children since the beginning of the 1980s. ${ }^{23-32}$ Nevertheless, although some countries have taken active steps to create conditions towards a rapid shift to $\mathrm{DBiBi}$, others still lag well behind in adopting this new educational approach. Very limited information is still available on forces that either promote or hinder the change towards this new educational approach, and considerable differences exist between countries as to the degree of application of such educational policy.

The need and right to communicate and to have full and equal access to all aspects of life is a basic human right for all people, but in particular, for Deaf people. ${ }^{13} 1433-35$ Moreover, Deaf communities are no longer isolated local groups of individuals, but a global interlinked community that increasingly pursues political, social and cultural changes at a global level. Current DBiBi education initiatives in distant parts of the world are just one example of the globalised structure of such changes because most of these experiences are continuously influencing, assisting and learning from each other. The purpose of the present study was to identify international megatrends that influence the current Deaf bilingual education move worldwide by integrating the work of geographically distant experts who had never before been able to share their long experience in this field and by facilitating wide access to these strategic data for change. 


\section{METHODS}

The study employed the Delphi method to identify international megatrends in the current Deaf bilingual education move. ${ }^{36}{ }^{37}$ Sign language interpreters facilitated communication throughout the whole process, which included regular meetings with team members of the Spanish Confederation of Deaf People.

\section{Selection of experts}

As Delphi participants must be purposively (rather than randomly) selected ${ }^{38}$ on the basis of individual qualifications and characteristics, experts participating in our Delphi study were selected by a process known as "daisy chaining". ${ }^{39}$ In order to do this, 11 international organisations dealing with education of $d$ /Deaf children were identified. Where such a worldwide institution did not exist, we contacted a European organisation of similar characteristics in its place (box 1). Fifteen new institutions and individuals, whose assistance in the study was also requested, were suggested by these organisations, and key informants in the case of Australia. Proposals of experts were collected from December 2003 to May 2005.

In addition to consultation with international organisations involved in d/Deaf education, a literature review was also carried out. The following database systems were searched: MEDLINE, PsycLIT, Sociological Abstracts, ERIC, Dissertation Abstracts, and LIDAT. The following libraries were also consulted: Spanish Documentation and Studies Centre (SIIS), Spanish Institute of Migration and Social Services Library (IMSERSO), and the Documentation Department of the CNSE Foundation for the Suppression of Communication Barriers. For a preliminary literature search, Internet resources were also used in two ways: to identify additional experts and to search background information on potential participants. As material on the Internet is not subject to any standards or review processes, the following evaluation criteria were taken into account when using web resources: authorship, URL affiliation, content, source of information bias, and currency of information. Documents published in the web sites of several educational organisations, such as UNESCO and the European Agency for Development in Special Needs Education, were also consulted. The general terms "deafness and bilingual", "deaf* and bilingual education", "deaf education", "deaf and bibi", "sign language and education and bilingualism" were used to initiate the search. As specific keywords, major subject headings and thesauri were identified, the respective terms

Box 1 International organisations involved in d/Deaf education identified and contacted for the selection of panel members

- World Federation of the Deaf (WFD)

- International Federation of Hard of Hearing People (IFHOH)

- European Association of Cochlear Implant Users (EURO-CIU)

- European Disability Forum (EDF)

- Fédération Européenne de Parents d'Enfants Déficients Auditifs (FEPEDA)

- European Federation of Teachers of the Deaf (FEAPDA)

- International Association of Logopedics and Phoniatrics (IALP)

- European Forum of Sign Language Interpreters (EFSLI)

- International Bureau for Audiophonology (BIAP)

- European Society for Mental Health and Deafness (ESMHD)

- United Nations Educational, Scientific and Cultural Organisation (UNESCO) were further researched. Works in English, French, Portuguese and Spanish were considered in the selection of potential experts. Works included published and, in some cases, unpublished material, such as journal articles, books, theses and dissertations, conference proceedings and government and corporate reports. Finally, the e-mail addresses of each of the potential participants were found on the Internet.

A list of 39 potential participants were identified as a result of consultation with international organisations. Twenty-two (56.41\%) were women and 17 (43.58\%) were men. Twelve experts were Deaf, one was hard of hearing, 15 were hearing, and 11 were not specified by nominators and could not be identified by searching the Internet. This list was augmented by 102 new potential participants identified through a literature review. Finally, six new potential panellists were also nominated by three respondents to the round 1 questionnaire. Potential participants included university teaching staff and researchers, journal editors, book editors, teachers of the $\mathrm{d} /$ Deaf, policy makers, presidents and members of national associations for the Deaf and activists. Table 1 shows the distribution of potential experts by country. As a result of the "daisy chaining" process, the final potential expert panel comprised 132 potential participants from 22 different countries.

\section{Round 1 questionnaire and analysis}

A round 1 questionnaire was sent to the selected experts by e-mail from May to June 2005 along with a covering letter inviting them to participate in the study. In the questionnaire, participants were asked to respond to the following two questions: "In your opinion, what are the five main forces/issues that, in the international context, have promoted the change towards the current Deaf bilingual education move?" and "In your opinion, what are the five main forces/issues that, in the international context, have hindered or prevented the change towards the current Deaf bilingual education move from happening?". A supporting letter from the Spanish Confederation of Deaf People was also sent to all Deaf non-respondents to foster their involvement in the study. In addition, a first reminder letter and questionnaire were sent to unresponsive participants urging them to complete and return the questionnaire in the following weeks.

The panel members generated 269 comments on essential elements for and 266 barriers against the current Deaf bilingual education move in response to the first round of questions. In order to synthesise individual participant responses and reduce the number to a manageable level, each response was read through by three independent raters (a Deaf expert on d/Deaf education and two hearing researchers, one from general and sign linguistics and education, and one from public health experienced in the Delphi technique $)^{40}$ and grouped by similarity of response into common topical categories and subcategories. In a second stage, categories were reviewed, discussed and agreed upon and a general coding framework was generated. In discussion, modifications were mainly made to the naming of a particular category and the inclusion or exclusion of some subcategories. Once the coding framework consisting of seven categories and 19 subcategories of responses for question 1 and 10 categories and 13 subcategories for question 2 was agreed upon, the three independent raters (RO, MLE and IMB) used it to group all panellists' responses. A concordance analysis was carried out in order to estimate the degree of agreement between raters: $89.59 \%$ for question 1 and $98.12 \%$ for question 2. Two other raters (CAD and MTR) arbitrated those responses when RO, MLE and IMB could not reach a consensus. Finally, initial responses within each category were condensed into statements without altering the essential 
Table 1 Number of potential participants identified as a result of consultation with international organisations involved in $\mathrm{d} /$ Deaf education, literature searches and respondents to the round 1 questionnaire by country

\begin{tabular}{|c|c|c|c|c|}
\hline Country & Consultation to organisations & Literature searches & Respondents to round 1 & Total \\
\hline Argentina & & 3 & & 3 \\
\hline Australia & 3 & 3 & & 6 \\
\hline Austria & 1 & & & 1 \\
\hline Canada & & 3 & & 3 \\
\hline Colombia & & 4 & & 4 \\
\hline Denmark & 3 & 2 & & 6 \\
\hline England & 3 & 6 & 1 & 10 \\
\hline Finland & 3 & & & 3 \\
\hline France & & 1 & & 1 \\
\hline Germany & 1 & 1 & & 2 \\
\hline Greece & 1 & & & 1 \\
\hline Holland & & 1 & & 1 \\
\hline Ireland & 1 & & 2 & 3 \\
\hline Italy & 1 & & & 1 \\
\hline Japan & & 2 & & 2 \\
\hline Norway & 2 & & & 2 \\
\hline Russia & & 2 & & 2 \\
\hline Sweden & 10 & 7 & & 17 \\
\hline Switzerland & & 1 & & 1 \\
\hline The Netherlands & 1 & 1 & & 2 \\
\hline Uruguay & & 1 & & 1 \\
\hline United States & 9 & 48 & 3 & 60 \\
\hline Non-identified & & 1 & & 1 \\
\hline Total & 39 & 87 & 6 & 132 \\
\hline
\end{tabular}

meaning of individual responses and according to the frequency with which each subcategorised response was brought up.

\section{Round 2 questionnaire and analysis}

Once responses to the first questionnaire had been analysed and categorised, a second questionnaire was developed from these initial responses. As the purpose of this second round questionnaire was to reach either a reliable consensus or a trend towards a consensus on whether or not to consider round 1 categorised responses as key factors having an impact upon the current Deaf bilingual education move, only the five categories that did meet the highest level of consensus among the first round respondents were included in the second round questionnaire. Respondents were asked to rate differently each category according to their own perception of its importance for the current Deaf bilingual education move on a five-point Likert-type scale scored as follows: 1, extremely important; 2, very important; 3, important; 4, moderately important; and 5, less important. Individual scores of each force/issue with the same ranking were first summed and then multiplied by the score weight to determine each weighted score. Then, all of the weighted scores were added to determine the total weighted score so that each force/issue could be compared. The study was deemed complete after two rounds as a result of a number of factors. First, the difficulty in maintaining participant involvement in subsequent rounds because of geographical distance and the dispersion of panellists. Second, an acceptable degree of convergence of opinion seemed to have been reached for the purpose of the analysis.

Table 2 Number of completed questionnaires, hearing status, sex, regions and language used to answer the questionnaire

\begin{tabular}{lcc}
\hline & Round 1 & Round 2 \\
\hline $\begin{array}{l}\text { Completed questionnaires } \\
\text { Hearing status }\end{array}$ & $54(40.9 \%)$ & $41(75.92 \%)$ \\
$\quad$ Deaf & $12(22.22 \%)$ & $9(21.95 \%)$ \\
$\quad$ Hard of hearing & $1(1.85 \%)$ & $0(0.0 \%)$ \\
Hearing & $41(75.92 \%)$ & $32(78.04 \%)$ \\
Sex & & \\
Female & $30(55.55 \%)$ & $23(56.09 \%)$ \\
Male & $24(44.44 \%)$ & $18(43.9 \%)$ \\
Region & $31(57.4 \%)$ & $28(68.29 \%)$ \\
Europe & $17(31.48 \%)$ & $8(19.51 \%)$ \\
USA and Canada & $4(7.4 \%)$ & $4(9.75 \%)$ \\
Latin America & $1(1.85 \%)$ & $1(2.43 \%)$ \\
Australia & $1(1.85 \%)$ & $0(0.0 \%)$ \\
Asia & & $37(90.24 \%)$ \\
Language & $50(92.59 \%)$ & $4(9.75 \%)$ \\
English & $4(7.4 \%)$ & \\
Spanish & & \\
\hline
\end{tabular}


Table 3 Results from round 1 of the Delphi survey: frequencies and percentages of statements within each categorised response, for each of the two questions

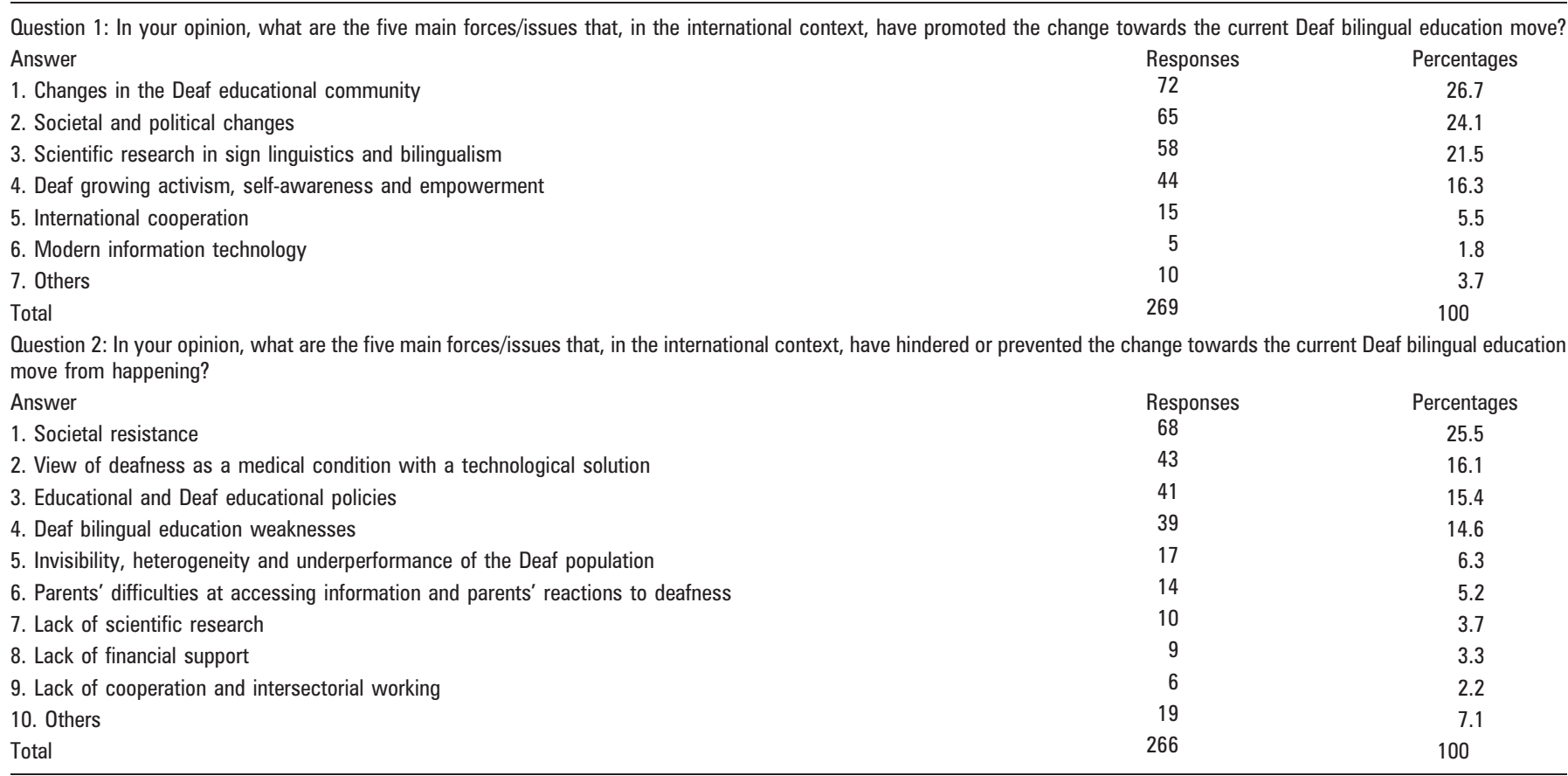

\section{RESULTS}

\section{Round 1}

In round 1, the following response rates were achieved: 76 of the 132 potential participants $(57.57 \%)$ responded to the round 1 questionnaire after a total of three requests. From the 76 respondents to the first iteration, a total of 54 (40.9\%) completed the questionnaire (21 identified through consultation with international organisations involved in $\mathrm{d} /$ Deaf education, 30 through a literature review and three by nomination of other panellists). Table 2 shows the number and characteristics of experts completing the round 1 questionnaire. The final list of categories (seven for question 1 and 10 for question 2) ordered by the frequency of panellists' individual responses are shown in table 3.

1. Societal and political changes, such as: a growing awareness, acceptance, recognition and changing attitudes and perspectives towards bilingualism, diversity and Deaf issues by society; an increased recognition of rights of minority groups, human/civil rights and disability movements; growing political activism demanding increased rights and education of Deaf people with an international legal recognition of sign languages by states and international organisations; and the recognition of the Deaf as a linguistic and cultural minority as well as an ideological shift from the medical model to a social model in interpreting human difference.

2. Growing Deaf activism, self-awareness and empowerment. Emancipation, self-advocacy, desire to control their own needs, and greater activism on the part of the Deaf community and Deaf associations worldwide as well as Deaf people's growing awareness of their linguistic human rights, own culture, identity and status. Moreover, Deaf people increasingly have more formal education, employment opportunities and international contacts. They also hold political/educational positions in decision-making organisations, are accepted into academia, and have teaching jobs within Deaf education programmes.

3. Scientific research in sign linguistics and bilingualism. Mostly, international research in linguistics of sign languages, bilingualism (language acquisition and learning, language and cognitive development, and second language learning) and bilingual education; and to a lesser extent, research on Deaf education, the sociology of the Deaf community, gender studies and pedagogy. Research findings have led to the acceptance and recognition of sign languages as real and legitimate languages and of the Deaf communities as bilingual communities.

4. Changes in the Deaf educational community. Mainly, the failure of previous Deaf educational models (oralism and total communication) and the disappointment about other educational alternatives together with advances in the knowledge, recognition and acceptance of bilingual programmes for other language minorities, Deaf bilingual programmes and the important role of sign language in communicative, cognitive and social development of Deaf children; and, although to a lesser extent, teachers' increased involvement, commitment and training and parents' attitudes, involvement and access to sign language.

5. International cooperation. International conferences, seminars and workshops leading to the sharing, exchange and dissemination of information and educational practices. A rise in the cooperation between deaf associations and parents' associations, Deaf associations and the mass media, Deaf and hearing teachers, and bilingual education researchers and linguistics researchers. Also, cross-national contact between Deaf people and their allies as well as cooperation between countries with a large experience in Deaf bilingual education and countries where bilingual programmes have just started. 
1. View of deafness as a medical condition with a technological solution. Continued dominance of a medical model of deafness in society and strong opposition to sign languages from professions based on a disability understanding of Deaf children. Medical ambition to cure deafness, medical professions' refusal to think of the Deaf as a linguistic and cultural minority and physicians' control over parents' decisions, giving them erroneous information about sign language and one-sided information about the possibilities of new technologies. The rise and widespread dissemination of cochlear implants giving the impression that deafness will be eliminated and sign language will be unnecessary and/or an obstacle for oral/aural therapy, and pharmaceutical funding and power behind implantations.

2. Phonocentrism and societal resistance to the unknown. The fact that society is strongly focused on sound and speech, social reactions towards the unknown (ignorance, fear of deafness, patronising and/or oppressive attitudes towards Deaf people, sign language and bilingual education, prejudice against and ingrained resistance to sign language), and social policies restraints. Also, and to a large extent, society's lack of knowledge about sociolinguistic issues in general (mostly, incorrect focus on language form instead of communication, lack of knowledge about bilingualism and bilingual education programmes and a belief that sign language impedes spoken language) and about Deaf issues in particular.

3. Educational and Deaf educational policies. To a great extent, the strong push towards mainstreaming of $\mathrm{d} /$ Deaf children as the national policy worldwide; also, inbuilt conservatism/inertia of educational systems and Deaf education. Deaf education programmes are still predominantly controlled by "old school" educators who are unfamiliar with and/or reluctant to use modern practices. Moreover, there is strong pressure and advocacy from oral institutions to maintain their educational model, and lack of Deaf professionals within the educational programmes; and finally, although to a lesser extent, new trends (resurgence of oralism) in the education of d/Deaf children because of cochlear implants in some countries.

4. Deaf bilingual education weaknesses. Mainly, the lack of training programmes of Deaf bilingual education for teachers, the lack of consistent standards for hiring teachers of the $\mathrm{d} /$ Deaf and lack of trained educators to carry out Deaf bilingual education programmes. Also, the continued reluctance and resistance of certain hearing educators to learn sign language, change oral methods and make room for $\mathrm{d} /$ Deaf colleagues. Also, the lack of resources for developing appropriate educational materials and curricula, the failure to explain what bilingualism/biculturalism really means and the lack of information about successful bilingual programmes.

5. Invisibility, heterogeneity and underperformance of the $\mathrm{d} /$ Deaf population. The diverse nature and low incidence of the $\mathrm{d} / \mathrm{Deaf}$ population. Political and tactical weakness of the Deaf community who have not succeeded in articulating their needs, demands, desires and reality. Deaf people's lack of possibilities to gain access to higher education because of constant communication barriers and discrimination and Deaf professionals' continued exclusion from educational systems and decision-making positions influencing changes in Deaf education.

\section{Round 2}

In round 2, a total of 41 questionnaires was returned, giving a response rate of $75.92 \%$ compared with the first round and $31.06 \%$ compared with those approached to take part in round 1. Table 2 shows the number and characteristics of experts completing the round 2 questionnaire.

The results of the ratings from round 2 to respondents are reported in box 2 and 3. Box 2 lists the five top themes and supporting statements as rated by members of the panel in answer to question 1. In order of importance, the themes included: (1) societal and political changes; (2) growing Deaf activism, selfawareness and empowerment; (3) scientific research in sign linguistics and bilingualism; (4) changes in the d/Deaf educational community; and (5) international cooperation. In answer to question 2, box 3 lists the five top themes and supporting statements in order of importance; the most important being: (1) the view of deafness as a medical condition with a technological solution; followed by (2) phonocentrism and societal resistance to the unknown; (3) educational and d/Deaf educational policies; (4) Deaf bilingual education weaknesses; and (5) invisibility, heterogeneity and underperformance of the $\mathrm{d} /$ Deaf population.

\section{DISCUSSION}

Our findings, which partly parallel those reported from previous research, reveal that issues of community development, political context, a medical/social framework for thinking about health, scientific research, cooperation, and educational processes are closely entwined. Furthermore, the most outstanding finding of our study is derived from the methodology used to gather expert input. By asking respondents to prioritise each previously identified statement, our results point out that social/political changes towards a growing acceptance of diversity and Deaf issues, and a medical/social view of Deaf people's health can promote or limit Deaf people's educational options much more than changes within the education sector that have important implications for policy makers and health planners.

A major strength of this study, in contrast to previous research on Deaf needs using the Delphi method, is including $\mathrm{d} /$ Deaf researchers in the monitor team and in the panel of experts to assure both Deaf and hearing perceptions of international megatrends influencing Deaf bilingual education. By doing so, this study has been an attempt to guarantee Deaf people's more equitable possibilities to partake in decisions affecting their own education, ${ }^{13}{ }^{41}$ and therefore their health.

A number of limitations might have influenced the findings of this study. On the one hand, selecting potential participants through recommendations from institutions posed an important difficulty because there is no database available comprising all international organisations involved in the education of $d /$ Deaf children, and therefore their selection, representatives' names and contact details had to be obtained in collaboration with the Spanish Confederation of Deaf People and the use of the Internet (box 1). This fact may have influenced the participation rate in this first stage of the "daisy chaining" process, as reflected by the high number of reminder letters sent out regarding the completion of this first information questionnaire and the need to extend the request to new organisations and individuals. On the other hand, literature searches and contacting potential participants by e-mail may also have created a number of limitations to the study. First, there is a risk that our findings reflect Deaf education clichés 
because literature searches necessarily miss people who may have something to contribute on the topic of interest but have not published anything, and recommendations from institutions are limited only to those who are known to the institutions. Second, our study may show a bias in the geographical distribution of participants; besides, works from Africa and Asia (except Japan) neither emerged from the literature review process nor were experts from these countries suggested by consultation with international organisations. Finally, unreliable contact details may also have restricted panellists' responses. Despite these potential limitations, the overall response, 54 panel members (40.9\%), represents a wide body of opinion and a desirable number in terms of both response reliability and study logistics.

Education of $d$ /Deaf children is an area that has undergone intensive reform around the world, in particular in recent decades. All these changes have, however, often occurred alongside a generalised perception that substantial changes in the provision of disabled children's education, like any other educational change, stem mainly from each country's own educational system. Nevertheless, considerable research has reported that a broad perspective is needed in understanding and planning any social change. What is more, Lee ${ }^{42}$ pointed out that one of the challenges for public health at present is understanding how globalisation and the health of specific individuals and population groups are micromacro linked, which means "capturing the transnational nature of many health determinants and outcomes" (p. 619). As education is a main determinant of health and a very strong predictor when making healthy choices, a move in the direction of understanding and mapping the interrelationships between the main promoting and hindering forces to a Bilingual-Bicultural educational approach for Deaf children at a transnational level is needed. The overall objective of this study was to identify and obtain a rank-ordered list of these transnational forces. Davies ${ }^{24} 43$ highlighted scientific research, political and social changes, cooperation between parents, teachers, researchers and Deaf adults, and changes within the educational community as the main supporting factors of DBiBi education in Sweden and Denmark. Likewise, Mas ${ }^{44}$ and Rinne $^{45}$ reported five main types of constraining factors to its provision and implementation in France and the United States: sociopolitical, financial, educational, parental and philosophical. Although the results of our study show that Deaf people's long struggle for equal opportunities is one of the most influencing forces towards DBiBi education, this factor does not always stand out in the existing literature. It is also worth noting that cooperation is reported as a promoting or hindering factor depending on the country of origin of the study. Two other findings are also particularly noteworthy: first, our finding that lack of financial support is not perceived by panellists as one of the five top barriers to the change stands in contrast to earlier research in which economic difficulties are pointed out as a very strong inhibiting factor; second, it is interesting that panellists' identification of technological advances as an element of DBiBi education has not been reported in previous investigations. These similarities and differences may reflect the fact that earlier research was aimed at explaining supporting and constraining factors at a local, regional or national level, whereas ours has a broader transnational focus. It would also explain why our results are more consistent with those reported by Lynch $^{15}$ on barriers to inclusion in the education of disabled children worldwide. Also, another possible reason is that our results were obtained directly from participants in contrast to most previous studies.

Whereas schools with a DBiBi model provide a favourable setting for achieving genuine equalisation of opportunities for all and full participation, their success requires a concerted effort, not only from teachers, peers and parents, but also from a number of different stakeholders in education at different levels: local, national, and international. At each level, stakeholders with various roles and responsibilities may be supportive or undermining. For example, it is well known that health providers are key stakeholders in promoting a healthy start in life for $\mathrm{d} /$ Deaf children and assisting their families. As 90-95\% of d/Deaf children are born to hearing parents, for these parents with no knowledge of deafness, most opinions about ensuring a healthy psychological, social and educational development for their $\mathrm{d} /$ Deaf children will come from the field of medicine. Most primary-care doctors are, however, extremely unlikely to have any $d$ /Deaf awareness or knowledge of the Deaf community, ${ }^{4}$ may well believe that children who do not hear necessarily need their hearing mechanism to be "repaired" by means of technological instruments-cochlear implants being the most recent-forgetting, as many times before in history, the linguistic human rights of Deaf children and the opinions of the Deaf community. ${ }^{12} 4647$ Consequently, the provision of healthcare services to Deaf people based only on a medical model of health becomes highly undermining, as findings in this study have pointed out, instead of supportive of Deaf children's needs. Accepting and recognising Deaf people as a linguistic and cultural minority no more "impaired" than any other language and cultural minority in an increasingly recognised multilingual world; that is, promoting a social model of health to Deaf children and their families, is one of the first steps needed to meet the requirements of Deaf children in an effective and equitable manner.

The results of this study suggest that a change towards $\mathrm{DBiBi}$ requires, as much as in any other sector, if not more, the help of a sound general strategic process based on a careful consideration of present and future megatrends in $\mathrm{d} /$ Deaf education and on the needs and expertise of Deaf people themselves. We therefore encourage the application of strategies for the development, implementation, sustainability, and improvement of DBiBi school programmes to be multi and intersectoral and require concerted efforts of a variety of players with many different interests.

\section{What is already known on this subject}

Education is a basic prerequisite for $d /$ Deaf people's health

- Changes in $d /$ Deaf education vary considerably in pace and effect from country to country and we still know very little about the reasons for such variation

\section{What this paper adds}

- Experts' consensus opinion about international megatrends that either promote or hinder the change towards the current Deaf bilingual education move worldwide

- The three most important promoting factors identified were: societal and political changes towards a growing acceptance of diversity and Deaf issues; growing Deaf activism, selfawareness and empowerment; and scientific research in sign linguistics and bilingualism

- The three most important hindering forces were: the view of deafness as a medical condition with a technological solution; phonocentrism and societal resistance to the unknown; and educational and $\mathrm{d} /$ Deaf educational policies. 
Gaining an understanding of how promoting forces may be amplified and hindering forces counteracted as well as information exchange, networking and cooperation of people and/or organisations who are in a position to influence future $\mathrm{d} /$ Deaf educational trends should be an area of further research.

Acknowledgements: The authors wish to thank the respondents in the first and second rounds, who generously shared their reflections and ideas, and to the 41 experts who completed the whole process - many with thoughtful comments. Special thanks are also due to the Observatory of Public Policies and Health (OPPS) and the Research Unit Linguistics Applied to Sign Languages of the University of Alicante as well as to the Spanish Confederation of Deaf People for their invaluable support and cooperation. Thanks also to all colleagues and students who contributed to this study, in particular Bryn Moody and Marian Aleson for enhancing the quality of the text itself.

Funding: This study is part of a research project, entitled "Investing in health: basis for a benchmarking study on the Spanish d/Deaf education", funded by the Spanish Medical Research Council no. PI021068.

Competing interests: None declared.

\section{REFERENCES}

1. WHO Europe. HEALTH 21. The health for all policy framework for the WHO European Region. Denmark: WHO Library Cataloguing in Publication Data, 1999.http:// www.euro.who.int/document/health21/wa540ga199heeng.pdf (accessed 19 Jan 2003).

2. WHO. Report of the International Workshop on Primary Ear and Hearing Care. Cape Town, South Africa: WHO, 12-14 March 1998 WHO/PBD/PDH/00.10. http://www.who.int/pbd/ deafness/activities/en/capetown final report.pdf (accessed 2 Nov 2005).

3. Padden C, Humphries T. Deaf in America: voices from a culture. Cambridge, MA: Harvard University Press, 1988.

4. Clowes B, ed. INCLUDE Deaf Europeans. UK: European Society for Mental Health and Deafness Secretariat, 2000.

5. Kyle J, Allsop L, Griggs M, et al. Deaf health in Scotland. Issues for deaf people in health promotion. Report to the Health Education Board for Scotland. Executive summary. Bristol: Centre for Deaf Studies, University of Bristol March 1997. http:// www.bris.ac.uk/Depts/DeafStudies/research/papers/HEBSEXEC.htm (accessed 14 Apr 2000).

6. Groce N. HIV/AIDS and people with disability. Lancet 2003;361:1401-2.

7. Obinna J, Krueger S, Osterbaan C, et al. Understanding the needs of the victims of sexual assault in the deaf community: a needs assessment and audit. Doc. 212867. Council on Crime and Justice, October 2005. http://www.ncjrs.gov/pdffiles1/nij/ grants/212867.pdf (accessed 15 Oct 2006).

8. WHO Task Force on Research Priorities for Equity in Health, WHO Equity Team. Priorities for research to take forward the health equity policy agenda. Bull WHO 2005;83:948-53. http://www.who.int/bulletin/volumes/83/12/948.pdf (accessed 2 Oct 2006).

9. Michailakis D. Government action on disability policy. A global survey. Stockholm: Fritzes kundtjänst, 1997 http://www.independentliving.org/standardrules/ UN_Answers/UN.pdf (accessed 24 Feb 2003).

10. European Parliament. Report on the proposal for a council decision on the European Year of People with Disabilities 2003 (COM(2001) 271-C5-0306/2001-2001/ 0116(CNS)). Doc. A5-0377/2001. Committee on Employment and Social Affairs; 29 October 2001. http://www.europarl.eu.int (accessed 29 Oct 2001).

11. Wilcox S. Struggling for a voice: an interactionist view of language and literacy in Deaf education. In: John-Steiner V, Panofsky CP, et al, eds. Sociocultural approaches to language and literacy: an interactionist perspective. New York: Cambridge University Press, 1994;vii:109-38.

12. Phillipson R, ed. Rights to language. Equity, power, and education. Celebrating the 60 th birthday of Tove Skutnabb-Kangas. Mahwah, NJ: Lawrence Erlbaum Associates, 2000.

13. United Nations. Standard rules on the equalization of opportunities for persons with disabilities. Resolution 48/96. 20 December 1993. http://www.un.org/esa/socdev/ enable/dissre00.htm (accessed 28 Feb 2005).

14. UNESCO. World Conference on Special Needs Education: Access and Quality. ED-95/ WS/2. Salamanca, Spain, 7-10 June 1994. Paris: UNESCO, 1994 http:// unesdoc.unesco.org/images/0009/000984/098427eo.pdf (accessed 24 Feb 2005).

15. Lynch J. Inclusion in education: the participation of disabled learners. ED 2001/WS/ 24. World Education Forum. Education for All 2000 Assessment; 26-28 April 2000; Dakar, Senegal; France: UNESCO; 2001. http://unesdoc.unesco.org/images/0012/ 001234/123486e.pdf (accessed 20 Oct 2003).

16. McConkey R. Understanding and responding to children's needs in inclusive classrooms. A guide for teachers. ED-00/WS/34. Paris: UNESCO Division of Basic Education; 2001 http://unesdoc.unesco.org/images/0012/001243/124394e.pdf (accessed 14 Jan 2005).

17. World Federation of the Deaf. Report on the status of sign language by the WFD Scientific Commission on Sign Language. Helsinki: WFD, 1993.
18. European Parliament. Resolution on sign languages for the deaf. Doc. A2-302/87. Friday, 17 June 1988. http://www.europarl.eu.int (accessed 2 Feb 2001).

19. European Parliament. Resolution on sign languages. Doc. B4-0985/98. 18 November 1998. http://www.europarl.eu.int (accessed 2 Feb 2001).

20. European Parliament. Resolution on the situation as regards fundamental rights in the European Union (2000) (2000/2231(INI)). PE 302.216/DEF. 5 July 2001. http:// www.europarl.eu.int (accessed 5 July 2001).

21. Knoors H, ed. The educational integration of the Deaf. Final Report of Helios-group 6. Brussels: European Commission, 1996.

22. Bergmann A, Ravn T, eds. Deaf language culture. Project "EUDECU" supported by the EU Programme SOCRATES 1999-2000. Desterlbergen (Belgium): vzw Cultuur voor Doven, 2000

23. Tervoort BT. The status of sign language in education in Europe and the prospects for the future. In: Kyle JG, Woll B, eds. Language in sign. London: Croom Helm, 1983:135-46.

24. Davies SN. The transition toward bilingual education of deaf children in Sweden and Denmark: perspectives on language. Sign Language Studies 1991;7:169-95.

25. Ahlgren I, Hyltenstam K, eds. Bilingualism in deaf education. Hamburg: Signum, 1994.

26. Mason DG. Bilingual/bicultural deaf education is appropriate. Occasional Monograph Series, Number 2. York University, Toronto, Ontario: Association of Canadian Educators of the Hearing Impaired, March 1994.

27. Heiling K. Bilingual vs. Oral Education: a comparison of academic achievement levels in deaf eighth-graders from two decades. Paper presented at the $18^{\text {th }}$ International Congress on Education of the Deaf. Tel Aviv, Israel, 16-20 July 1995.

28. Lewis W, ed. Bilingual teaching of deaf children in Denmark: description of a project, 1982-1992. Aalborg, Denmark: Doveskolernes Materialcenter, 1995.

29. Mashie SN. Educating deaf children bilingually. Washington DC: Gallaudet University Press College Programs, 1995.

30. Strong M. A review of bilingual/bicultural programs for deaf children in north America. Am Ann Deaf 1995;140:84-94.

31. Knight P, Swanwick R. Working with deaf pupils: sign bilingual policy into practice. London: David Fulton Publishers, 2002.

32. Power D, Leigh G, eds. Educating deaf students: global perspectives. Washington DC: Gallaudet University Press, 2004.

33. UNESCO. The world declaration on education for all: meeting basic learning needs and framework for action: meeting basic learning needs. The World Conference on Education for All 1990, Jomtien, Thailand, 5-9 March 1990. http://www.unesco.org/ education/efa/ed_for_all/background/world_conference_jomtien.shtml (accessed 24 Feb 2005).

34. European Parliament. Resolution on the Communication from the Commission to the Council, the European Parliament, the Economic and Social Committee and the Committee of the Regions - Towards a barrier-free Europe for people with disabilities (COM(2000) 284 - C5-0632/2000 - 2000/2296(COS)). PE 286.259/DEF. 4 April 2001. http://www.europarl.eu.int (accessed 4 Mar 2001).

35. Siegel L. The argument for a constitutional right to communication and language. J Deaf Stud Deaf Educ 2002;7:258-66. http://jdsde.oxfordjournals.org/cgi/reprint/7/ 3/258 (accessed 1 Jun 2006).

36. Linstone $\mathbf{H}$, Turoff M, eds. The Delphi method: techniques and applications. Addison Wesley Advanced Book Program; 1975. Ed. 2002. http://www.is.njit.edu/pubs/ delphibook/delphibook.pdf (accessed 22 May 2006).

37. Adler M, Ziglio E. Gazing into the oracle: the Delphi method and its application to social policy and public health. Bristol, PA: Jessica Kingsley Publications, 1996.

38. Akins RB, Tolson H, Cole BR. Stability of response characteristics of a Delphi panel: application of bootstrap data expansion. BMC Med Res Methodol 2005;5:37. http:// www.biomedcentral.com/1471-2288-5-37.pdf (accessed 10 Feb 2006).

39. Gordon TJ. The Delphi method. In: Glenn JC, ed. Futures research methodology series. Washington DC: United Nations University, 1994.

40. Ortiz MR, Álvarez-Dardet C, Ruiz MT, et al. Identificación de barreras a las políticas de nutrición y alimentación en Colombia: estudio por el método Delfos. Rev Panam de Salud Publica 2003;14:186-92.

41. European Parliament. Report on the proposal for a council decision on the European Year of People with Disabilities 2003 (COM(2001) 271-C5-0306/2001-2001/ 0116(CNS)). Doc. A5-0377/2001. Committee on Employment and Social Affairs. 29 October 2001. http://www.europarl.eu.int (accessed 4 Mar 2001).

42. Lee K. A dialogue of the deaf? The health impacts of globalisation. J Epidemiol Community Health 2001;55:619.

43. Davies SN. Attributes for success. Attitudes and practices that facilitate the transition toward bilingualism in the education of deaf children. In: Ahlgren I, Hyltenstam K, eds. Bilingualism in Deaf education. Hamburg: Signum, 1994:102-21.

44. Mas C. Bilingual education for the Deaf in France. In: Ahlgren I, Hyltenstam K, eds. Bilingualism in Deaf education. Hamburg: Signum, 1994:71-81.

45. Rinne MG. Potential barriers to implementing a bilingual/bicultural program for deaf children. Sign Language Studies 1996;93:327-55

46. Munoz-Baell IM, Ruiz MT. Empowering the deaf. Let the deaf be deaf. J Epidemiol Community Health 2000;54:40-4.

47. Blume SS. Histories of cochlear implantation. Soc Sci Med 1999,49:1257-68. 